\title{
Interpretation of Kipling's Ideal Empire Construction
}

\author{
Marzidm Ayeou \\ Department of English Literature, The University of Aberdeen, UK \\ m.bouzid.09@aberdeen.ac.uk
}

\begin{abstract}
This article will locate the ambivalence of colonial discourse in the poetical work of Rudyard Kipling, the writer who most clearly articulated the imperial spirit of his age and is often regarded as the unofficial laureate of British Empire. We will especially examine and highlight Kipling's conflicted positions that he held in relations to India and colonialism.Towards the end of this paper, we will assess the impact of such conflict on the power and authority of the Orientalist discourse.
\end{abstract}

Keywords: ambivalence, imperial discourse, British Empire, India, Orientalism, poetical dissonance.

\section{Kipling's Imperial Poetics}

Of course no one would deny that Rudyard Kipling was the imperial bard of British Empire. Critics and commentators have unanimously perceived him as an arch priest of jingoism, racism and imperialism. Orwell saw him as 'the prophet of British imperialism in its expansionist phase. ${ }^{\text {, }} \mathrm{H}$. E. Bates wrote of his 'love of the most extravagant form of patriotism' which likened him to Hitler. ${ }^{2}$ In fact, in his close association with the imperial affair of his country, Kipling was often compared to chief colonial icons of the age. Cyril Falls observed in 1915 that 'if the first name that association summoned to the mind on mention of the word Imperialism was that of Joseph Chamberlain, the second was undoubtedly Rudyard Kipling. ${ }^{3}$ D. C. Somervell has even gone far to suggest that Kipling's endeavour to British Empire had surpassed that of colonial officials for

[i]mperialism of the late Victorian period went deeper than any political action or political theory. Its greatest exponent was not Sir John Seeley, nor even Joseph Chamberlain, most notable of Colonial Secretaries. Imperialism was a sentiment rather than a policy; its greatest exponent was Rudyard Kipling. ${ }^{4}$

Thus has the latter been widely regarded as the bard of Empire and its unofficial laureate.

One of the major contributions of Kipling to the discourse of late Victorian imperialism is his emphasis on, and advocacy for, its religious quality. British imperialism claimed to be spiritually ordained and this claim sustained its legitimacy and perpetuation. In a lecture to students on 'How to study Natural History' in 1885, Charles Kingsley gave voice to the prevalent imperial ideology of his country when he observed that 'the glorious work which God seems to have laid on the

\footnotetext{
${ }^{1}$ George Orwell, 'Rudyard Kipling' in Kipling's Mind and Art: Selected Critical Essays, ed. by Andrew Rutherford (Stanford: Stanford University Press, 1966), pp.70-84, p.72.

${ }^{2}$ H. E. Bates, The Modern Short Story: A Critical Survey (Edinburgh: Thomas Nelson, 1941), p.111.

${ }^{3}$ Cyril Falls, Rudyard Kipling: A Critical Study (London: Martin Secker, 1915), pp.186-7.

4 D. C. Somervell, English Thought in the Nineteenth Century (London: Methuen, 1940), p.186.
}

English race' is 'to replenish the earth and subdue it'. ${ }^{5}$ What Kingsley had hinted Lord Curzon made explicit:

\begin{abstract}
Your task is to fight for the right, to abhor the imperfect, the unjust or the mean $[. .$.$] to care nothing$ for flattery, or applause or odium or abuse [...] but to remember that Almighty has placed your hand on the greatest of His ploughs, in whose furrows the nations of the future are germinating and taking shape, to drive the blade a little forward in your time, and to feel that somewhere among those millions you have left a little justice or happiness or prosperity, a sense of manliness or moral dignity, a spring of patriotism, a dawn of intellectual enlightenment, or a stirring of duty where it did not before exist-that is enough, that is the Englishman's justification in India. ${ }^{6}$
\end{abstract}

This was the Englishman's justification for imperialism not only in India but in every land. For the nation, as the Parliamentary Committee on Aborigines states in 1837, had been also 'signally blessed by Providence' to bring 'the knowledge of the true God to the uttermost ends of the earth' ${ }^{7}$ Thus British imperial mission had become a divine mission.

What Alan Sandison termed 'the invocation of might in support of right' formed the basis of Victorian imperialism, and of course a vehement insistence on it would not escape the work of Kipling. ${ }^{8}$ A poetic paraphrasing of Curzon and Buxton's words is heard in 'A Song of the English' (1893), the opening poem of The Seven Seas:

Fair is our lot- $\mathrm{O}$ goodly is our heritage!

\footnotetext{
${ }^{5}$ Charles Kingsley, Scientific Lectures and Essays, 19 vols (London: Macmillan, 1880), p. 308.

${ }^{6}$ Lord Curzon, quoted in George Bennett, The Concept of Empire: Burke to Attlee 1774-1947 (London: Adam and Charles Black, 1953), p. 351.

7 Great Britain Parliament. House of Commons. Select Committee on Aboriginal Tribes. Report of the Parliamentary Select Committee on Aboriginal Tribes, (British Settlements.). $1837 . \quad$ JSTOR, www.jstor.org/stable/60207475.

${ }^{8}$ Alan Sandison, The Wheel of Empire (London: Macmillan, 1967), p. 7.
} 
(Humble ye, my people, and be fearful in your mirth!)

For the lord our God Most High

He hath made the deep as dry,

He hath smote for us a pathway to

the ends of all the Earth! ${ }^{9}$

A solemn air of religiosity pervades throughout the poem. The mood of prayer is initially invoked by an allusion to the Book of Common Prayer version of Psalms 16:7. Despite his call for national humility the speaker cannot help boasting about his race being God's chosen, destined to rule the earth. The invocation of a spiritual justification for Britain's imperial mission recurs in many of Kipling's poems. In 'The Song of the Dead', a hymn to the men who made the Empire at the cost of their lives, Kipling heartens: 'Came the Whisper, came Vision, came the power with the Need, / Till the Soul that is not man's soul was lent us to lead' (11. 1213). According to Robert H. MacDonald, Empire-making becomes therefore in the process 'not so much a matter of will as of compulsion or even instinct, of obedience to a greater power, to a "Soul.", 10 Thus the advent of the imperial vision, as Ann Parry notes, 'mimics [...] the descent of the Holy Spirit.' 11

A similar strain of religiosity is carried over to 'Recessional', one of Kipling's most famous imperial anthems and with which he has come to be regarded, according to David Gilmour, as 'a national symbol., ${ }^{12}$ Like 'A Song of the English', 'Recessional' is based on the assumption that God has made a covenant with the English race and has granted them 'dominion over palm and pine':

God of our fathers, known of old,

Lord of our far-flung battle-line

Beneath whose awful Hand we hold

Dominion over palm and pine-

Lord God of Hosts, be with us yet,

Lest we forget-lest we forget!

The poem is rife with Biblical allusions and echoes. The main text, from which the refrain 'Lest we forget-lest we forget' is taken, is of course Deuteronomy, 6:12: 'Then beware lest thou forget the Lord, which brought thee out of the land of Egypt'. Likewise, the reference to the 'ancient sacrifice' as a 'humble and a contrite heart' (11. 9-10) is an allusion to Psalm 51:17: 'My sacrifice, O God, is a broken spirit; a broken and contrite heart you, God, will not despise'. While not particularly religious himself, Kipling valued the appeal of the sacred in approaching the secular.

\footnotetext{
${ }^{9}$ Rudyard Kipling, Rudyard Kipling: The Complete Verse (London: Kyle Cathie Limited, 1990), p.138, 11.1-5. This edition will be used in this thesis hereafter, unless is otherwise indicated.

${ }^{10}$ Robert H. MacDonald, The Language of Empire: Myths and Metaphors of Popular Imperialism 1880-1918 (Manchester: Manchester University Press, 1994), p.155.

${ }^{11}$ Ann Parry, The Poetry of Rudyard Kipling: Rousing the Nation(Buckingham: Open University Press, 1992), p.52.

${ }^{12}$ David Gilmour, The Long Recessional: The Imperial Life of Rudyard Kipling (London: John Murray, 2002), p.124.
}

He understood that the Old Testament was the appropriate language in which to preach about Empire. Hence, as stated by Gilmour, Kipling's hymns

are much more than rhymed editorials full of Old Testament sonorities and incantations. The biblical language and allusions appealed to people who had been educated not only through the Classics but through the Gospels, the Epistles and the Hebrew prophets as well. [Thus] they understood the message and they accepted it (Gilmour 2002: 118).

Although Kipling's imperial message is at its most humbleness in 'Recessional', as it warns of excessive national pride and imperialistic hubris, the poem on the whole is jingoistic in sentiment. Apart from his boastful assumption of a divine covenant made with the English race to rule the earth, Kipling indulges (if even inadvertently) in 'Such boastings as the Gentiles use, / Or lesser breeds without the Law-' (11. 21-22). The latter phrase in particular has been the subject of much controversy. Its relevant Biblical text is Paul's Epistle to the Romans where he warns: 'For as many as have sinned without law shall also perish without law' (2:12-15). Many critics, including Orwell, have been willing to interpret it as a mere reference to the Germans whom Kipling considered uncivilised and 'have no Law'. It is likely that Kipling had the Germans in his head when writing such phrase, yet in 'Recessional' he is certainly also referring to the subject peoples of British Empire; and Orwell's mental association of the phrase 'lesser breeds' with a picture 'of some pukka sahib in a pitch helmet kicking a coolie' bears ample testimony to its reference to 'natives' and non-white races (Orwell 1966: 71). Of course even if questionable here, Kipling still lays himself open to the charge of racialism elsewhere.

In fact, his most potent contribution to the colonial discourse lies in his racialist and Orientalist approach to the nonwhites. According to Said,

Kipling's White Man, as an idea, a persona, a style of being, seems to have served many Britishers while they were abroad. The actual color of their skin set them off dramatically and reassuringly from the sea of natives, but for the Britisher who circulated amongst Indians, Africans, or Arabs there was also the certain knowledge that he belonged to, and could draw upon the empirical and spiritual reserves of, a long tradition of executive responsibility towards the colored races. ${ }^{13}$

It was out of this tradition that a poem like 'The White Man's Burden' has emerged. The latter, published in 1899 in McClure's magazine, is one of Kipling's most (in)famous poems. It has come to stand as the poet's major articulation of the Orientalist discourse, and the phrase of 'the white man's burden' has become a euphemism for imperialism. The poem is specifically addressed to the United States,

${ }^{13}$ Edward W. Said, Orientalism (London: Penguin Books, 1978; repr. 1995), p. 226. 
congratulating her annexation of the Philippine islands and exhorting her to share with Britain the role of 'civilising' the backward regions of the earth since it was 'the fate of our breed to do these things' as Kipling told a correspondent in Connecticut: ${ }^{14}$

Take up the White Man's burden-

Send forth the best ye breed-

Go bind your sons to exile

To serve your captives' need;

To wait in heavy harness

On fluttered folk and wild-

Your new-caught, sullen peoples,

Half devil and half child.

The cheery rhyming scheme of ABCBDEFE is in tune with the whole celebratory temper of the poem. Also the regularity of the rhythmical pattern, with an alternating lines of iambic dimeter and amphibrach in the first line followed by iambic trimeter in the second, creates a feeling of an orderly, regimented march that matches the 'civilising', missionary mood. Thus the form of the poem is attuned to the theme of cheerleading and encouraging white men to go out and establish their order on the 'wild' peoples of the other half of the globe. The phrase 'White Man' here, tellingly capitalised and magnified as a significant abstraction, may be easily misunderstood as that of the 'lesser breeds' in 'Recessional'. As Gilmour clarifies, "white" here plainly refers to civilization and character more than to the colour of men's skins' (2002: 128). Be that as it may, the poem however is, to use the words of Keating, 'profoundly racist in sentiment.' 15 The Filipinos, and symbolically all natives and non-white races, are 'fluttered folk and wild', 'sullen peoples, / Half devil and half child', and very much given to 'sloth and heathen Folly' (11. 6-8 and 23). This negative description of the colonised seems to confirm Said's reading of 'Orientalism' as 'a western style for dominating, restructuring and having authority over the Orient' (1978: 3). The latter is depicted not only as being critically different, ignorant and in need of urgent intervention of Western civilisation and enlightenment, but also as being feeble, childish and incapable of ruling their own affairs. Natives, according to Kipling and like-minded Orientalists, could not be trusted to run things by themselves. This is the justification is usually given for British rule in India. Kipling told Margaret Burne-Jones once that '[i]f we didn't hold the land in six months it would be one big cock pit of conflicting princelets. ${ }^{16}$ The imperial task was often propagandised for as being a paternalistic task. As such, natives had to be treated, and represented, as children. Colonies, as Kipling informed a correspondent when the Filipinos started their revolt against the American colonisation in February 1899, were 'like babies [...] They

\footnotetext{
${ }^{14}$ Rudyard Kipling, The Letters of Rudyard Kipling 189099, 2 vols, (Iowa: University of Iowa Press, 1990), p. 344.

15 Peter Keating, Kipling the Poet (London: Secker \& Warburg, 1994), p. 120.

16 In TheLetters of Rudyard Kipling 1872-89, 1 vol,(Basingstoke: Macmillan, 1990), p.98.
}

are all very aggravating at first but they are worth it. ${ }^{17}$ This calls to mind Chamberlain's words at the Colonial Conference of 1897, when he observed that the colonies were 'still children, but rapidly approaching manhood.'18 According to imperialists, this 'manhood' is of course impossible to approach without their full guidance and control. Kipling declared in one of his short stories in Plain Tales from the Hills that no native could be trusted to rule because 'he is as incapable as a child of understanding what authority means, or where the danger of disobeying it. 19

Another way of 'Orientalising the Orient', as Said would have it, is the representation of them as being 'wild and strange.' This is particularly rife in Kipling's work. The epigraph to 'In the House of Suddhoo' (1886), for instance, reads:

\section{A stone's throw out on either hand}

From out that well-ordered road we tread,

And all the world is wild and strange.

Further, the wildness and strangeness of the world that the white man tries to rule is depicted in full colour in 'The Overland Mail'. The latter poem is first published in 1886 in Department Ditties, celebrating the postal service to British exiles in India. As observed by Keating, however, 'The Overland Mail' is more than a mere celebration of the postal service: it is actually 'one of Kipling's most unashamedly joyful endorsements of imperial endeavour, with the postal activity offered as a microcosm of the far-flung Empire' (Keating 1994: 21). That being so, the poem would seem apt for reading as a manifestation of Orientalism. From the very first stanza Kipling points up the exoticness and oddness of the land:

In the Name of the Empress of India, make way, O Lords of the Jungle, wherever you roam, The woods are astir at the close of the dayWe exiles are waiting for letters from Home. Let the robber retreat-let the tiger turn tailIn the name of the Empress, the Overland Mail!

This immediately paints a picture of India being not only exotic and different, but wild and dangerous. The landscape is referred to blatantly as a 'Jungle', and the poet warns of 'robbers' and 'tigers' that might hinder the delivery of mail from homeland to exiles. Moreover, the poem begins 'at the close of the day'. The 'brawny, brown' Indian runner needs to take his journey to the British exiles by night, in darkness, when he is expected to meet not only the ferocious 'Lords of the Jungle', but also the destructive gods of nature with torrents of water blocking his way and gusts of wind and tempests threatening his path (11. 13-15). Significantly, it is

\footnotetext{
${ }^{17}$ Kipling to Zogbaum, 6 Feb. 1899 in TheLetters of Rudyard Kipling 1890-99, 2 vol, (Basingstoke: Macmillan, 1990), p. 344.

18 Quoted in Andrew Porter, The Nineteenth Century (Oxford: Oxford University Press, p.1999), p. 339-40.

${ }^{19}$ Rudyard Kipling, 'His Chance in Life' in Plain Tales from the Hills, ed. by Andrew Rutherford (Oxford: Oxford University Press, 2009), p.61.
} 
only when the runner reaches the British exiles in the hill that the day breaks and the horrors of the Indian landscape vanish all of a sudden:

The world is awake and the clouds are aglow.

For the great Sun himself must attend to the hail:-

"In the Name of the Empress, the Overland Mail!"

The association of the British exiles with the serene daylight and the Indian landscape with the perilous night is exactly the kind of binary opposition which Said suggests is typical of Orientalism: in the presence of Western civilisation, light, calmness and order abide; otherwise darkness, violence and barbarity reside. The pattern of the asymmetrical oppositions that Kipling evokes through the Indian landscape is further reinforced by having the British exiles reside in the hills and the Indian runner move 'up, up through the night' to reach them. As John McLeod perceptively notes, even 'the geography of the poem seems to applaud the conquering British. ${ }^{20}$ The progressive movement is again an allegory of the transcendental dichotomy between a high, superior coloniser and a low, inferior colonised. This dichotomy would seem to confirm Said's argument that Orientalism divides the world into rigid binomial categories of "ours" and "theirs", with the former always encroaching upon the latter' (1978: 227). According to Said, such categorisation was reinforced during the nineteenth century not only by biological theories that set racial diversity (found in works such as Cuvier's Le Règne animal and Robert Knox's The DarkRaces of Man), nor even by Darwinian theses on survival and natural selection which accentuated the 'scientific' validity of the division of races into advanced and backward; such racial classification was also nurtured by a western cultural and institutional tradition of entrenching, and often enshrining, the binomial opposition between West and East in art and literature.

It was of this tradition that Kipling wrote, bluntly, his poem 'We and They':

We shoot birds with a gun

They stick lions with spears.

Their full-dress is un-.

We dress up to Our ears.

They like Their friends for tea.

We like Our friends to stay;

And, after all that, They look upon We

As an utterly ignorant They!

We eat kitchen food.

We have doors to latch.

They drink milk or blood,

Under an open thatch.

We have Doctors to fee.

They have Wizards to pay.

And (impudent heathen!) They look upon We

As quite impossible They!

\footnotetext{
${ }^{20}$ John McLeod, Beginning Postcolonialism (Manchester: Manchester University Press, 2012), p. 72.
}

The Orientalism of the above stanzas is unquestionable. 'They', by implication the Orients and all non-white races, are oddly different from 'We'. Unlike the civilised latter, the former are barbaric creatures who drink blood and live in wilderness unclothed, and are very much given to superstition and heathenism. Such is the stereotypical picture of natives: 'they' are unordered, unclean and prone to bestiality. For Orientalists, this is an inexorable truth. If the West is assumed to be the site of knowledge and civilisation, then it will follow that the East is a place of ignorance and barbarism: 'East is East, and West is West, and never the twain shall meet', in Kipling's own words. It is only by pointing up such difference that the Orientalist/imperialist is able, in Said's words, to 'control, manipulate, and even to incorporate, what is manifestly different' (1978: 12). Notwithstanding, does not 'incorporation' here stand in sharp contrast with 'control' and 'manipulation'? With all the former's connotations of merging, fusion and integration, can we not suppose then that the twain of East and West can actually meet and merge into one another more than Said, and Kipling's notorious verse, has allowed?

\section{Kipling's Subversive Poetics}

It is highly significant that critics such as Fred Reid and David Washbrook, who acknowledge the existence of 'strong affinities' between Kipling's political ideas and those contained in 'the official mind' of the I.C.S.' during the eighteen nineties, admit that 'Kipling's view of imperialism was a more complex one than his single, famous line quoted often out of context, "Oh East is East and West is West and never the twain shall meet.",21 On the misquotations of this line Charles Carrigton has also noted that '[n]o lines of Kipling's have been more freely quoted, and more often misquoted in exactly the opposite sense which Kipling gave them.' ${ }^{22}$ The charge of racism that is typically ascribed to the above line, and which implies that East and West are too different to understand each other, is in fact contradicted, as Gilmour notes, 'by the rest of the verse which asserts that two men of equal courage and ability can be equals despite multitudinous differences of class, race, nation and continent' (2002: 69):

\begin{abstract}
Oh, East is East, and West is West, and never the twain shall meet,

Till Earth and Sky stand presently at God's great Judgement Seat;

But there is neither East nor West, Border, nor Breed, nor Birth,

When two strong men stand face to face, though they come from the ends of earth!
\end{abstract}

\footnotetext{
21 Fred Reid and David Washbrook, 'Kipling, Kim and Imperialism', History Today, 32.8 (1982), 14-20 (pp. 18 and 14). Available at:

<URL:https://search.proquest.com/docview/1299043418?ac countid=8155>

${ }^{22}$ Charles Carrington, Rudyard Kipling: His Life and Work (London: Macmillan, 1955), p. 136.
} 
Actually, Kipling's controversial line is being contradicted not only by the rest of the verse, but also by the whole poem. The ballad tells the story of how an Afghan horse-thief, Kamal, and a Colonel's son, tellingly not named, discover friendship by recognising their similarities within their differences. The two equally-matched warriors who were the bitterest of enemies at the beginning, have come to deeply respect each other's courage and chivalry by the end: They have looked each other between the eyes, and there they found no fault. / They have taken the Oath of the Brother-inBlood on leavened bread and salt' (11. 84-5). To those who have detected an element of homoeroticism in the men's encounter, William Flesch has replied that the homoerotic bond 'is itself a metaphor for something else-for the possibility of a sublime transcultural or omnicultural moment of communication and understanding of just the kind of powerful gesture that the poem itself makes vivid for readers everywhere. ${ }^{23}$ Thus, in contrast to the apparent meaning of the opening line, Kipling shows that East and West can actually meet and, not just that, he also glimpsed the possibility that the former can even surpass the latter in matters of chivalry and leadership. Kamal offers his son to protect a British officer and 'ride at his left side as shield on shoulder rides'. Contrary to the typical imperialist representations of natives as being weak and in need of western protection and guidance, Kamal and his son have come to stand by the end of the poem as 'men of the Guides!'. In fact, by proposing his only son to defend the Colonel's, Kamal not only shows himself as a symbol of bravery and nobility, but also, as Flesch states, he 'sets himself up as a truer father, a more equal, more capable father then the Colonel is' (2010: 25). We may, therefore, go a long way towards agreeing with Kingsley Amis' final observation on the ballad's misinterpretations that: 'All that is clear is that Kipling understood and honoured men of other races more than any other English writer. ${ }^{24}$

Kipling's high respect for other races shows up more blatantly in 'The Mother Lodge' where he expresses his fondness for the Masonic Lodge and celebrates the mixture of men from all backgrounds. In this Lodge, as Kipling nostalgically depicts, the sense of brotherhood and unity is overwhelming and men care none for the colour of each other's skin or religion. Indeed, they spend all night talking about the God they know best:

An' man on man got talkin'

Religious an' the rest,

An' every man comparin'

Of the God 'e knew the best.

$[\ldots]$

Outside_-"Sergeant! Sir! Salute! Salaam!"

Inside-_Brother," an' it doesn't do no 'arm.

We met upon the Level an' we parted on the Square,

An' I was Junior Deacon in my Mother-Lodge out there!

(11. 33-64)

\footnotetext{
${ }^{23}$ William Flesch, The Facts On File Companion to British Poetry, $19^{\text {th }}$ Century (Port Orange: Port Orange Library, 2010), p. 25.

${ }^{24}$ Kingsley Amis, Rudyard Kipling (London: Thames \& Hudson, 1975), p. 54.
}

Discussing Kipling's 'limited' transcendence of racial barriers, George Shepperson has contended that the antithesis between the 'inside' and 'outside' realms in 'The Mother Lodge' reveals that 'there was no possibility of that brotherhood within the Lodge being carried over to society at large' and suggests that not in the slightest Kipling 'would wish it to be otherwise. ${ }^{25}$ One should like to bring forward to $\mathrm{Mr}$ Shepperson's attention however that the fact of writing a poem on this universal brotherhood is itself a suggestion of the poet's desire to carry it over not just to society at large but to the whole world. Shepperson is able to recognise that Kipling "was capable [...] of profound imaginative sympathy and understanding for Indians of many kinds', yet he believes that this 'did not shake his conviction of the superiority of the white, English-speaking peoples' (128-9). This might not be easily dismissed when we consider Kipling's entire work, yet one should also recognise that in 'the Mother Lodge', at least, it is the natives who are clearly made superior as among his 'Brethren black an' brown', Kipling was but a 'Junior Deacon'. Further, staggered by the religious diversity and tolerance among the native Masons, Kipling avows:

It often strikes me thus,

There ain't such things as infidels

Excep, per'aps, it's us.

If we take 'us' here as a usual Kiplingesque reference to his racial group of whites, then the lines above would bear an ample testimony to the poet's shaking conviction of the superiority of his caste. A scepticism that is equally voiced in his reference elsewhere to "the more than inherited (since it is also carefully taught) brutality of the Christian peoples, beside which the mere heathendom of the West Coast nigger is clean and restrained. ${ }^{26}$ One might argue that such statements were just articulated out of Kipling's well-known abhorrence to religious missionaries and their crude imposition of Christianity on subject peoples, yet one should also remember that in 'Gunga Din', the British soldiers whom Kipling usually venerates in his work are shot through with the same ignoble light.

The latter poem is a letter of respect and admiration from a British soldier to an Indian water-carrier, Gunga Din, who scarified his life for that of his master:

\author{
The finest man I knew \\ Was our regimental bhisti, GungaDin. \\ He was "Din! Din! Din! \\ "You limpin o' brick-dust, Gunga Din! \\ "Hi' Slippyhitherao! \\ "Water, get it! Panee Lao, \\ "You squidgy-nosed old idol, Gunga Din."
}

(11. 11-17)

${ }^{25}$ George Shepperson, 'The World of Rudyard Kipling' in Kipling's Mind and Art: Selected Critical Essays, ed. by Andrew Rutherford (Stanford: Stanford University Press, 1966), pp. 126-145, p. 129.

26 Rudyard Kipling, 'They' and The Brushwood Boy (London: Macmillan, 1925), p.34. 
Through reporting the demeaning, racist speech of British soldiers, the narrator reveals the amoral attitude of his fellow white men who are much given to insulting, humiliating and even beating their native servants or 'Bishti.' An attitude which has led to the speaker's recognition that Din 'was white, clear white, inside.' Here Kipling is challenging the traditional Orientalist association of 'white' with good and 'black' with evil: the British soldiers are white from the outside yet dark and evil from the inside; and Gunga Din though is black without, he is white and pure within. Din's inner pureness is made clear not just when he tended the wounded under fire, but also when he lost his life rescuing the British soldier:

'E carried me away
To where a dooli lay,
An' a bullet come an' drilled the beggar clean.
'E put me safe inside,
An' just before 'e died,
"I 'ope you liked your drink," sezGunga Din.
[...]
You Lazarushian-leather Gunga Din!
Though I've belted you and flayed you,
By the livin' Gawd that made you,
You're a better man than I am, Gunga Din!

Thus in 'Gunga Din' the betterness and superiority of natives is laid bare throughout.

However, there are some critics who, can only see the typical imperialist side of Kipling, have suspected the genuineness of such laudatory presentation of natives and celebration of human fraternity. Jonathan Raskin, for instance, who believes that 'apartheid' is Kipling's 'law of nature', argues that the latter strives to create such an amicable atmosphere in his colonial works because he 'wants us to remember the friendship [...] and forget about the exploitation of black and white, the oppressed by their oppressors. $^{, 27}$ I find it quite injudicious to make this view in light of such poem as 'Gunga Din' where the exploitation of natives is what most emphasised. Certainly it is the abuse of blacks by whites that one remembers most of all from 'Gunga Din', and not just the friendship. Raskin even goes so far as to propose that 'Kipling's characters offer fellowship to each other because they know their places, they accept the social hierarchy $[\ldots]$. He would shake any man's hand-black or white, rich or poor - if he defended the empire' (42-43). This seems to correspond exactly enough with George Shepperson's perception that 'Kipling's admired type of non-white was, in fact, the servant or subordinate such as Gunga Din [...] where the non-white was dissatisfied with his subordinate status [...] Kipling found little grounds for admiration' (1966: 127). One is compelled here to correct such parochial views and remind both Raskin and Shepperson of the fact that in such poems as 'The Ballad of East and West' and 'Fuzzy-Wuzzy' it is mostly the native rebellious warrior and fighters against the British rule who gained his approval and sparked his admiration.

\footnotetext{
27 Jonathan Ruskin, The Mythology of Imperialism (New York: Random House, 1971), pp. 42.
}

In the latter poem, Kipling lauds the Beja warriors, nicknamed as Fuzzy-Wuzzies, for their prowess and excellent fighting skills at the 1884 Battle of Tamai. While the poem as a whole is not totally free from some tinges of racism, as when the speaker calls the Fuzzies-Wuzzies 'pore benighted 'eathen' and 'big black boundin ' beggar', it is still notable for its expression of respect and admiration for the 'other'. In fact, the speaker's hesitancy and uncertainty are brought to the fore by the reiteration of the conjunction 'but':

You're a pore benighted 'eathen but a first-class fightin' man;

$[\ldots]$

The Burman give us Irriwaddy chills,

An' a Zulu impi dished us up in style:

But all we ever got from such as they

Was pop to what the Fuzzy made us swaller;

We 'eld out bloomin' own, the papers say,

But man for man the Fuzzy knocked us oller.

Then 'ere's to you, Fuzzy-Wuzzy, an 'the missis and the kid:

Our orders was to break you, an' of course we went an did.

We sloshed you with Mattinis, an 'it wasn't 'ardly fair; But for all the odds agin' you, Fuzzy-Wuz, you broke the square.

In his attempt to 'exonerate' Joseph Conrad's novel Heart of Darkness from the charges of racism, Fetson Kalua has paid a particular attention to the portrayal of the narrative persona, Charles Marlow, who 'displays hesitancy and uncertainty about what he sees and speaks'. Kalua refers to several instances in the text when Marlow 'tempers what are overtly racist observations and assertions with qualifying words such as "but", According to Kalua, Conrad's use of this technique of qualification was in order to 'draw the reader's attention to the fact that Marlow is conflicted and hence engaged in a struggle within himself to come to an understanding of colonial representations of "otherness.",28 Put another way, Marlow is presented as a metaphor for the ironies and contradictions of the colonial enterprise, emphasising thusHomiBhabha's idea of ambivalence ${ }^{29}$ which Kalua argues is at the heart of the novella.

In a similar vein, in his treatment, or rather critique, of Said's concept of Orientalism and its application to Kipling's Indian material , B. G. Moore-Gilbert contends that the latter at times 'fails to make aesthetic sense of his political convictions', concluding that 'uneasiness' can be

\footnotetext{
${ }^{28}$ Fetson Kalua, 'Locating the Ambivalence of Colonial Discourse in Joseph Conrad's Heart of Darkness', Current Writing, 26.1 (2014), 12-18, (p. 13). Available at: <URL: http://dx.doi.org/10.1080/1013929X.2014.897462>. 29 InThe Location of Culture,BhabhaadaptedThe term 'ambivalence' which was first developed in psychoanalysis to describe a continual fluctuation between wanting one thing and its opposite into colonial discourse theory to describe the complex mix of attraction and repulsion that characterises the relationship between coloniser and colonised (London: Routledge, 1994).
} 
the defining character of his work. According to MooreGilbert, such 'uneasiness' of Kipling is reflected especially through his narrative techniques. For instance, Kipling's employment of an unreliable and unstable narrative persona in his Indian fiction in addition to his predilection for the gothic have disquieting effects and reflect a sense of anxiety in the writer's political views. Gothic conventions, as Moore-Gilbert explains,

are often employed by writers prior to Kipling [as we have already seen with Tennyson] to unsettle the reader and deprive him of that secure sense of authorial control which would be the appropriate fictional analogue of confident imperial rule. ${ }^{30}$

In that respect, Moore-Gilbert argues that the ambiguity of the gothic mode, combined with the use of a complex narrative persona, "would seem to bear productively upon Said's argument about the critical relationship of "narrative" to "Orientalism." Moore-Gilbert considers particularly Said's comparison of the real dynamics of Orientalism to the 'executive power of bureaucracy in public administration' as invalid because he believes that the 'discourse is not so monolithic and powerful as such a comparison might imply' (Said 1978: 234; Moore-Gilbert 1986: 197).

The latter viewhas been a commonplace among Said's critics. Perhaps the first reference was /goes to Dennis Porter's early essay first published in 1983, 'Orientalism and Its Problems', in which he argues that within colonial texts 'there arise textual dissonance that constitute a challenge to western hegemonic thought', adding that 'a reading that uncovers doubt and contradiction within a canonical work obviously raises the possibility of counter-hegemonic energies. ${ }^{, 31}$ Porter describes Orientalism as a discourse 'in a state of tension' and thus he disapproves of its claimed monolithism or rigidity (1994: 154). According to Porter, one of the major challenges that arises from Said's Orientalism is its ignorance of the capacity of literary works for 'internal ideological distanciation'; that is, literary texts 'may in their play establish distance from the ideologies they seem to be producing' (160). Thus, the discourse of Orientalismis not as homogeneous and monolithic as Said has allowed and the colonial narratives, as our analysis of Kipling's imperial poetics has revealed, are embedded with dissonant discourses which inspire far more subversive readings than hitherto perceived.

\section{References}

[1] Amis Kingsley, Rudyard Kipling (London: Thames \& Hudson, 1975)

[2] Bates H. E., The Modern Short Story: A Critical Survey (Edinburgh: Thomas Nelson, 1941)

\footnotetext{
${ }^{30}$ B. J. Moore-Gilbert, Kipling and "Orientalism" (London: Croom Helm, 1986), pp. 178-9 and p. 189.

${ }^{31}$ Dennis Porter, 'Orientalism and Its Problems' in Colonial Discourse and Post-Colonial Theory, ed. By Patrick Williams and Laura Chrisman (New York: Columbia University Press, 1994), pp. 150-171, pp. 155-56.
}

[3] Bennett George, The Concept of Empire: Burke to Attlee 1774-1947 (London: Adam and Charles Black, 1953)

[4] BhabhaHomi K., The Location of Culture (London: Routledge, 1994)

[5] Carrington Charles, Rudyard Kipling: His Life and Work (London: Macmillan, 1955)

[6] Falls Cyril, Rudyard Kipling: A Critical Study (London: Martin Secker, 1915)

[7] Flesch William, The Facts On File Companion to British Poetry, $19^{\text {th }}$ Century (Port Orange: Port Orange Library, 2010)

[8] Gilmour David, The Long Recessional: The Imperial Life of Rudyard Kipling (London: John Murray, 2002)

[9] KaluaFetson, 'Locating the Ambivalence of Colonial Discourse in Joseph Conrad's Heart of Darkness', Current Writing, 26.1 (2014), 12-18.

[10] Keating Peter, Kipling the Poet (London: Secker \& Warburg, 1994)

[11] Kingsley Charles, Scientific Lectures and Essays, 19 vols (London: Macmillan, 1880)

[12] Kipling Rudyard, 'They' and The Brushwood Boy (London: Macmillan, 1925)

[13] Kipling Rudyard, Plain Tales from the Hills, ed. by Andrew Rutherford (Oxford: Oxford University Press, 2009)

[14] Kipling Rudyard, Rudyard Kipling: The Complete Verse (London: Kyle Cathie Limited, 1990)

[15] Kipling Rudyard, TheLetters of Rudyard Kipling 187289, 1 vol, (Basingstoke: Macmillan, 1990)

[16] Kipling Rudyard, TheLetters of Rudyard Kipling 1890 99, 2 vol, (Basingstoke: Macmillan, 1990)

[17] MacDonald Robert H., The Language of Empire: Myths and Metaphors of Popular Imperialism 18801918 (Manchester: Manchester University Press, 1994)

[18] McLeod John, Beginning Postcolonialism (Manchester: Manchester University Press, 2012)

[19] Moore-Gilbert B. J., Kipling and "Orientalism" (London: Croom Helm, 1986)

[20] Orwell George, 'Rudyard Kipling' in Kipling's Mind and Art: Selected Critical Essays, ed. by Rutherford Andrew (Stanford: Stanford University Press, 1966)

[21] Parry Ann, The Poetry of Rudyard Kipling: Rousing the Nation (Buckingham: Open University Press, 1992)

[22] Porter Andrew, The Nineteenth Century (Oxford: Oxford University Press, p.1999)

[23] Porter Dennis, 'Orientalism and Its Problems' in Colonial Discourse and Post-Colonial Theory, ed. By Patrick Williams and Laura Chrisman (New York: Columbia University Press, 1994) 